\title{
From Schools to Higher Education \\ - neoliberal agendas and implications for autonomy
}

\begin{abstract}
Neoliberal agendas have acted to limit the agency of groups and of individuals through both the imposition of boundaries and through setting up rigorous systems of accountability which together act to codify behaviours. Such systems do not so much remove freedom as influence conceptions about the alternatives available. ${ }^{1}$ In this article we outline the English educational policy context and the pressures placed upon first primary schools and then Higher Education establishments, considering the extent to which accountability and an emphasis on the needs of the individual impact on leadership behaviours in schools and upon academic freedoms in Higher Education. Boundaries to individual or group agency are explored drawing together lessons about the limits on professionals in these two situations.
\end{abstract}

Hammersley-Fletcher, L. and Qualter A. (2010) “Chasing improved pupil performance: the impact of policy change on school educators' perceptions of their professional identity, the case of further change in English schools" British Educational Research Journal 36, 6, 903-917; DOI: 10.1080/01411920903215853

\footnotetext{
${ }^{1} \mathrm{~S}$ Marginson, 'Hayekian neo-liberalism and academic freedom' (Keynote address to Philosophy of Education Society of Australia, Women's College, University of Sydney, 23 November 2006)
} 


\section{From Schools to Higher Education}

\section{- neoliberal agendas and implications for autonomy}

\section{Introduction}

The ubiquitous rise of neoliberal philosophy over recent decades has transformed the economic and social landscapes of many countries across the world. Political leaders have promoted the deregulation of the economy, trade liberalisation together with the dismantling of health and education systems in order to achieve higher rates of profit. $^{2}$ More local versions included Thatcherism and Reaganomics with Globalisation involving the spread of neoliberal values across national boundaries. ${ }^{3}$ Neoliberalism has recently been described by Nobel prize winning economist ${ }^{4}$ as 'that grab-bag of ideas based on the notion that markets are self-correcting, allocate resources efficiently and serve the public well'. This approach has had a fundamental impact on education ${ }^{5}$ influencing government views of the contribution that education can make to society, how that contribution ought to be governed and ultimately how educational institutions can be made to operate within a market driven economy. In this article we set out to discuss and explore how the neoliberal agenda has influenced two separate sites of educational delivery in England. We begin by briefly outlining the underlying tenets of neoliberalism. We then illustrate the ways in which neoliberal ideals have brought about change through a more critical consideration of first primary schools and then Higher Education. Thus we consider the ways in which this process of narrowing the boundaries within which primary school teachers can manoeuvre has been achieved in England, and the extent to which those boundaries may be broader or narrower depending on the ways in which leaders implement required changes. We then seek to understand the impact of changes on academics and to examine ways in which these might be alleviated. Through taking these two localised examples of neoliberal policy in action we aim to demonstrate the similarity of managerial pressures upon educators, albeit in rather different settings, and suggest the likely outcomes of these pressures for both teacher agency and academic freedom.

\section{Context}

In the 1960's and 70's education, health and other social institutions were funded on the basis that they would contribute to the general improvement in the stock of human capital, with the underlying assumption that there is a direct link between the quality of workers and productivity. Consequently education, health and community

\footnotetext{
${ }^{2}$ C Vilas 'Democratisation in Central America', Journal of Latin American Studies 28 (2) (1996): $461-503$

${ }^{3}$ L Morely Quality and Power in Higher Education (Buckingham, Society for Research in Higher education and Open University Press, 2003)

4 J Stiglitz 'The End of Neoliberalism' Daily News Egypt July 7th 2008

${ }^{5} \mathrm{G}$ Whitty, 'Moving beyond recent education reform - and towards a democratic professionalism' (Paper presented at the International symposium on education reform and teachers, Hitotsubashi University, Tokyo, November 2005)
} 
are considered to be of high value to society as a whole. ${ }^{6}$ The thrust of the neoliberal agenda has been that economic prosperity is linked to the individual rather than to society as a whole, and hence that the social good is maximised by the extension of a market that encompasses all human transactions. ${ }^{7}$ Thus education and health are viewed as products that can be bought and sold. The shift therefore has been from one of a concern for the common good to one of individual freedom. The freedom on offer is however, regulated. Neoliberal agendas serve to impose boundaries within which organisations and people may operate by codifying ways of behaving, introducing rigorous systems of accountability and requiring organisations to put in place structures for the management of these systems that ensure compliance. ${ }^{8} 9$ Marginson ${ }^{10}$ argues that such systems do not remove freedom, but rather that they limit personal and group agency in specific ways so that freedom is restricted within narrow boundaries.

\section{The concept of 'Lopsidedness'}

How far neoliberal policies are successful in bringing about the changes desired by its champions has been the subject of some debate. ${ }^{11}{ }^{12}$ Harvey $^{13}$ noted that, although the neoliberal direction of travel has come to be similar across the world, development has been 'lopsided' (p13) depending on the various political, traditional and historical forces at play. For example Thatcher's version of neoliberalism was more ideologically driven than Regan's more pragmatic route. In the UK much 'creative destruction' ${ }^{\prime 14}$ of institutions was achieved, although marketisation of the precious health service was a step too far with Mrs Thatcher forced to assure the people that health care would be 'free at the point of delivery'. On the other hand the utilities, and railways were privatised with far less resistance, despite cries of 'selling off the family silver' by Harold McMillan a traditional, one nation Conservative. Therefore we argue that lopsidedness is apparent at the National Level. Similar differences can be seen amongst the policy directions adopted by different countries within the UK. Menter et $\mathrm{al}^{15}$ looked at the impact on teachers' work of sociocultural and geopolitical changes which in turn inform national policy towards education and schools. They found that policy developments in England were much more centralist

\footnotetext{
${ }^{6}$ B Davies and P Bansel, 'Neoliberalism and education', International Journal of Qualitative Studies in Education 20, (3) 247-259

${ }^{7}$ D Harvey, A Brief History of Neoliberalism (Oxford: Oxford University Press, 2005)

${ }^{8}$ OPSR Reforming our Public Services: Principles into Practice (London: Office of Public Services Reform, 2002)

${ }^{9}$ E Hoyle and M Wallace, Educational Leadership: Ambiguity, Professionals and Managerialism (London: Sage, 2005)

${ }^{10}$ S Marginson, 'Hayekian neo-liberalism and academic freedom' (Keynote address to Philosophy of Education Society of Australia, Women's College, University of Sydney, 23 November 2006)

${ }^{11}$ G Esping-Andersen, Welfare States in Transition: National Adaptations in Global Economies, (London: Sage, 1996)

12 J Clarke, 'A world of difference? Globalization and the study of social policy' in: G Lewis, S Gewirtz and J Clarke, Rethinking social policy (London: Open University/Sage, 2000)

${ }^{13}$ D Harvey, A Brief History of Neoliberalism (Oxford: Oxford University Press, 2005)

${ }^{14}$ D Harvey, A Brief History of Neoliberalism (Oxford: Oxford University Press, 2005: 3)

${ }^{15}$ I Menter, P Mahony and I Hextall, 'Ne'er the twain shall meet?: modernizing the teaching profession in Scotland and England' Journal of Education Policy 19 (2) (2004): 195-214
} 
and included more private sector organisations, while in Scotland a more consultative approach was adopted with little involvement of the private sector. Menter et al concluded that the consequences, in terms of a greater sense of freedom for teachers in Scotland and greater control and mistrust of teachers in England were tied to the new found confidence of Scotland on devolution, and its history of seeing education as a means to address social and personal development. Thus at International and National level the magnitude of the impact of neoliberalisation has meant that the extent to which institutions and individuals might exercise agency could vary dramatically. Hence, as Menter et al imply, the impact on professional freedom and, by extension, professional identity may vary according to the extent to which neoliberal agendas reach into particular institutions and the individuals operating in them.

Robertson ${ }^{16}$ argues that the implementation of markets was used to shape criticism of educational institutions, initially focussing on schools and colleges, as being bureaucratic and unresponsive to the needs of the customer (parents, carers and students). Similarly, as Clegg ${ }^{17}$ suggests, the principles espoused in a 1988 report by the World Bank lead the government to see traditional universities as the main obstacles to the marketisation of education and the management of knowledge produced by research. As a consequence the emphasis on market mechanisms led to a restructuring of education which, beginning with schools and colleges, uses the notion of choice as a key instrument for improvement. ${ }^{18}$ Further this restructuring was based on the belief that most problems can be solved by the introduction of new systems or regulations and the rigorous adherence to those that are in place. We now turn to the literature on change within the primary school sector before moving on to look at Higher Education.

\section{Changes in schools}

In pursuing a neoliberal agenda which 'stresses competitiveness, accountability and audit, $^{19}$ governments across the world have promoted a rapid growth in new managerialism with attempts to adopt management techniques from the private sector to achieve gains in efficiency and effectiveness. ${ }^{20}$ In schools in England this has led to an increased emphasis on improving leadership and management where structures are put in place to ensure that leaders are competent in the art of working within restricted parameters to implement government policy, and where, according to Hoyle ${ }^{21}$ "They may become so acculturated to the vision articulated by

\footnotetext{
${ }^{16}$ S L Robertson, 'Teachers' Work, Restructuring and Post-Fordism: Constructing the New "Professionalism"' in I G Goodson and A Hargreaves Teachers' Professional Lives ( London: Routledge, 1996)

${ }^{17} \mathrm{P}$ Clegg, 'Creativity and Critical Thinking in the Globalised University' Innovations in Education and Teaching International 45 (3) (2008) 219-226

${ }^{18}$ D Hursh 'Neo-liberalism, Markets and Accountability: transforming education and undermining democracy in the United States and England', Policy Futures in Education 3 (1) (2005) 3-15

${ }^{19}$ A Jackson, 'Teachers, the reluctant professionals: a call for an individual response' (Paper presented at BERA, Warwick 6-9 Sept 2006)

${ }^{20}$ A Beckman and C Cooper, (2004) "'Globalisation", the New Managerialism and Education: Rethinking the Purpose of Education in Britain', Journal for Critical Education Policy Studies, 2 (2) online at: http://www.jceps.com/?pagelD=article\&articlelD=31 (accessed January 2009)

${ }^{21}$ E Hoyle, Educational Leadership : Ambiguity, Professionals and Managerialism (London: Sage, 2005) 68
} 
policymakers that they are totally committed to achieving it". This explains the significant emphasis that has been placed on leadership training for English school Head Teachers, middle managers and other key staff. This training is provided not through the universities but, for the most part, through the centrally controlled National College for School Leadership (NCSL), either directly or franchised out through competitive bidding. ${ }^{22}$ The NCSL was explicitly set up to lead the discourse on school leadership. In this way, as Gunter and Fitzgerald ${ }^{23}$ argue, Head Teachers have been hijacked by policy makers to do their bidding in schools.

Our argument is that those who are in leadership posts have been given a job to deliver reforms in such a way that they are having to micro-manage people's lives and work. Centralised and branded 'New Labour' reform means that every aspect of school life curriculum, lessons, assessment, communication, quality - is described, itemised, monitored, weighed and judged by those external to the school who need someone internally to effectively deliver and be accountable. ${ }^{24}$

We have argued above that histories play a part in the ways in which neoliberal political pressures influence the behaviours of institutions and the individuals within them. In order to consider how far primary school teachers have been able to retain their professional identities we need to consider the history of English primary education.

As Blenkin and Kelly ${ }^{25}$ have highlighted, post-World War 2 English primary schooling was characterised (and perhaps caricatured) by an emphasis on the development of the individual and pupil autonomy. There was a strong belief in the value of developing an egalitarian society and progressive teaching principles were associated with such ideals. These ideals began to come under fire as images of teaching without clear aims and purpose were promulgated, and the then prime minister James Callaghans', Ruskin College Speech in 1976 brought such concerns into the public arena. ${ }^{26}$ This opened debate on the rights of teachers to control 'the secret garden of the curriculum'. ${ }^{27}$ Consequently progressive ideals gave way to a much greater emphasis on control and accountability. ${ }^{28}$ Green $^{29}$ described the

\footnotetext{
22 P Denley and S Leaton- Gray 'The "New Professionalism” - rhetoric and reality? A view from the quagmire' (Paper presented at the British Educational Research Association Annual Conference, University of Glamorgan, September 14-17,,2005)

${ }^{23} \mathrm{H}$ Gunter and T Fitzgerald, 'The Future of leadership Research' School Leadership and Management 28 (3) (2008) 261-279

${ }^{24} \mathrm{H}$ Gunter and T Fitzgerald: 263

${ }^{25}$ G Blenkin and A Kelly, The Primary Curriculum: a process approach to curriculum planning, (London: Paul Chapman Publishing, 1987)

${ }^{26}$ G Kirk, 'The Growth of Central Influence on the Curriculum' in B Cosin, M Flude and M Hales School Work and Equality: A reader, (London: Hodder and Stoughton, 1989)

${ }^{27}$ H C Hansard Deb (21 March vol 620 cc39-180 $\left.\underline{39} \underline{40}, 1960\right)$

${ }^{28}$ B Moon 'The National Curriculum: Origins and context' in T Brighouse and B Moon, Managing the National Curriculum: some critical perspectives, (London: Longman, 1990)

${ }^{29} \mathrm{P}$ Green 'Chalk Circles: the curriculum as an arena of conflict' in M Galton and B Moon, Changing Schools....Changing Curriculum. (London: Harper-Rowe, 1983)
} 
1970 's as a period where, in opposition to the widely practised autonomy model of education, there was a growing feeling that balance needed to be restored. These moves culminated in the 1988 Education Reform act, which introduced a National Curriculum. This not only formalised what was to be taught but also procedures for inspecting schools. Alongside the prescription of curriculum in the 1988 Education Reform Act there were moves towards greater autonomy, through increased powers of school governors and open enrolment. These contradictory pressures for the centralisation of control over policy and direction, together with pressures for the decentralisation to local control of implementation and resource management, led to changes which Hopkins and Lagerweij ${ }^{30}$ argued, made it difficult to make a real difference to the quality of schooling whilst making the whole system more complex. ${ }^{31}$ Thus freedoms to lead schools creatively were equally subject to restrictive practices so that as Gunter ${ }^{32}$ has argued, such practices simply served to reinforce centralised managerialism.

In the mid 1990's the then Teacher Training Agency developed standards for subject leaders in schools and as Hammersley-Fletcher ${ }^{33}$ argues schools quickly began to identify ways in which they could extend the work of the then 'curriculum coordinators' in anticipation of the new emphasis on subject leadership. However, when asked about their new role and change of nomenclature to 'leader' threequarters of the teachers interviewed rejected this re-labelling. It was clear that their images of leadership were orientated around hierarchical interpretations of what leaders are, an unsurprising finding given the models in operation in their schools at that time. "I can sort of see the 'tweed', sort of marching through in the morning saying, 'Follow me, girls'" Primary school curriculum leader $9 .{ }^{34}$ This quotation whilst culturally situated in nature, demonstrates the image held by teachers of a rather autocratic leader who expected others to follow them without question. Schools tended to view themselves as generally collegial institutions formally led by the headteacher and in primary schools in particular the notion of developing new layers of leadership appeared to be nonsensical. The apparent tension created from both a growing interest in the ways in which people can work together and an emphasis on a leadership that operates at many levels within schools led bodies such as the National College for School Leadership to encourage schools to re-define traditional notions of hierarchical leadership in terms of 'distributed leadership'. Headteachers were positioned as powerful actors who could extend the boundaries of leadership through recognising expertise rather than formal position as the basis of leadership

\footnotetext{
${ }^{30}$ D Hopkins and N Lagerweij, 'The school improvement knowledge base' in D Reynolds, R Bollen, B Creemers, D Hopkins, L Stoll and N Lagerweij, Making Good Schools - linking school effectiveness and school improvement, (London: Routledge, 1996)

${ }^{31} \mathrm{~K}$ Bullock, C James and I Jamieson, 'The process of educational management learning' in L Kydd, M Crawford and C Riches Professional Development for Educational Management, (Buckingham: Open University Press, 1995)

${ }^{32} \mathrm{H}$ M Gunter, Leaders and Leadership in Education, (London: Paul Chapman Publishing, 2001)

${ }^{33}$ L Hammersley-Fletcher, 'Becoming a Subject Leader: what's in a name' School Leadership and Management, 22 (4) (2002): 407-420

${ }^{34}$ L Hammersley-Fletcher:416
} 
roles within groups. The influence of such thinking was recorded in data reported by Hammersley-Fletcher and Brundrett, ${ }^{35}$

...we are working together as a team, building up a good... um, teamwork skills so that one person isn't just 'oh follow me l'm the leader' but 'come on we can all work together on this' ... Core subject leader

The emphasis on working together and acting as a team was a marked response in the interviews reported and demonstrates the extent to which the NCSL had influenced the agenda of leadership practice. Hammersley-Fletcher and Brundrett also note the extent to which headteachers reported their own practices as supporting models of distributed leadership, despite rather contradictory evidence from the staff that they worked with. Thus the rhetoric about the benefits of shared leadership was undoubtedly having an impact.

More recently the workforce remodelling agenda claims to provide opportunities for all staff to get involved in setting school wide agendas with a shift in emphasis towards the importance of learning for all in the school community. This agenda was hailed as offering schools freedoms from the centralised models of the recent past handing control back to the schools themselves. As Hammersley-Fletcher and Adnett $^{36}$ argue, workforce remodelling was,

primarily designed to reduce constraints on school-level decisionmaking and enable schools more freedom to develop their own solutions to meeting the government's key objective of raising standards

Nevertheless despite the fact that as one headteacher, in the research reported by Hammersley-Fletcher and Adnett $^{37}$ stated, ". . . remodelling has just given us . . . a licence and I feel now that I've got the confidence ..." (Headteacher) they go on to argue that, "It seems likely that much of the activity around remodelling is largely acting to support the status-quo rather than acting to challenge and re-think educational practice and leadership". ${ }^{38}$ Robertson $^{39}$ argues that educational remodelling has been held up as a promise of a new professionalism for teachers despite criticisms by $\mathrm{Smyth}^{40}$ that it is no more than subterfuge, concealment and distortion by a state that wishes to retreat from the responsibility of having to provide

\footnotetext{
${ }^{35}$ L Hammersley-Fletcher and M Brundrett, 'Leaders on Leadership: the impressions of primary school headteachers and subject leaders' School Leadership and Management 25 (1) (2005): 59-75; 65

${ }^{36} \mathrm{~L}$ Hammersley-Fletcher and N Adnett, 'Reassignment or Redefinition? Workforce Remodelling at the national and school level in England' Educational Management, Administration and Leadership 37 (2) (2009): 181-198; 182

${ }^{37}$ L Hammersley-Fletcher and N Adnett: 194

${ }^{38}$ L Hammersley-Fletcher and N Adnett: 196

${ }^{39}$ S L Robertson, 'Teachers' Work, Restructuring and Post-Fordism: Constructing the New "Professionalism"' in I G Goodson and A Hargreaves Teachers' Professional Lives ( London: Routledge, 1996)

40 J Smyth, 'A Socially Critical View of the Self-Managing School' Education Links 42 (1993): 23-9
} 
quality education. Gunter ${ }^{41}$ argues that remodelling operates to distance teachers from the classroom using this time to design schemes for others (ie: non-teachers) to implement, with the implication that curriculum and pedagogic knowledge bears no relationship to successful or creative delivery.

The shifts outlined above have led academics such as Ball ${ }^{42}$ to argue that despite a long history of autonomy and responsibility for children's' learning and the curriculum, English teachers sense of professional identity had become fragmented. Intensification of workloads and greater central control have acted to challenge professionalism with Dadds ${ }^{43}$ going so far as to argue that teachers are becoming increasingly viewed as 'technician' rather than as autonomous professional. The consequent inroads into teacher professionalism are demonstrated through work such as that of Forrester ${ }^{44}$ which indicates that leaders are more anxious to do a good job in terms of inspection findings than in doing a good job for children they teach. Perhaps we should ask how far the heavily managed professional can be seen as a true professional when autonomy, and knowledge are so changed and where responsibility is to the system and not directly to the children. That the goal of teachers to get good results and positive inspection reports has become acceptable practice (albeit at an unconscious level) is a clear demonstration of the need to stand back and question practices that are taken for granted. This may also be symptomatic of what Patterson ${ }^{45}$ argues to be the increasing assertion of the individual as a result of increasingly consumerist models of society. Tomlinson ${ }^{46}$ argues, somewhat sceptically in relation to government purposes, that if government is truly interested in promoting social justice and inclusion agendas then there is a need for 'some leadership towards re-developing the notion of the common good' ${ }^{47}$ across the education sector.

Having argued above that the primary teacher as a professional has changed beyond recognition, such that professional identities are severely challenged by the lack of autonomy, recent research has pointed to ways in which the implementation of the neoliberal agenda can be 'lopsided' even at the level of different primary

\footnotetext{
${ }^{41} \mathrm{H}$ Gunter, 'Remodelling the School Workforce in England: a study in tyranny' Journal for Critical Education Policy Studies 5 (1) (2007): 1-11 http://www.jceps.com/?pagelD=article\&articlelD=84 (accessed Jan 2009)

${ }^{42} \mathrm{~S} J$ Ball, 'The teacher's soul and the terrors of Performativity' Journal of Educational Policy 18 (2) (2003): 215238

${ }^{43} \mathrm{M}$ Dadds, 'Continuing professional development: Nurturing the expert within' Journal of In-Service Education 23(1) (1997): 31-38

${ }^{44} \mathrm{G}$ Forrester, 'All in a day's work: primary teachers "performing" and "caring"', Gender and Education 17 (3) (2005): 271-287

${ }^{45}$ L Patterson, Education and the Scottish Parliament, (Edinburgh: Dunedin Academic Press, 2000)

${ }^{46} \mathrm{~S}$ Tomlinson, Education in a Post-Welfare Society: Introducing Social Policy (Berkshire: Open University Press, 2005)

${ }^{47}$ S Tomlinson: 222
} 
schools. In a study by Hammersley-Fletcher and Qualter ${ }^{48}$ it was reported that, where head teachers were able to nurture a sense of collegiality and encourage nonteaching staff to develop skills and knowledge, teachers were able to retain a focus on the things they considered important, the child and their development. Hammersley-Fletcher and Qualter ${ }^{49}$ concluded that,

in the schools researched the self-confidence of staff appeared to be related to how the changes were instigated. Where implementation was thoughtful and developmental, staff confidence was maintained and thus their sense of professional identity protected.

Thus, where Head Teachers took an approach that protected their staff from the pressure to comply quickly and took the time to develop all staff, teachers were able to retain their sense of self and to work collegially to shared (if externally as well as internally set) goals. The role of the manager therefore is crucial and the outcome 'lopsided' in that some schools retain in their staff a strong professional identity while in others this is challenged. Further, recent national strategies urge schools to network both with other schools and with the wider community involved in childrens services. This too may offer opportunities for teachers to re-think their positions in a way that enables them to alter the boundaries of constraint and to think more creatively about future practice.

\section{Changes in Universities}

Davies et $\mathrm{al}^{50}$ writing from an Australian perspective suggest that management replaced leadership as the primary role of university presidents and Vice Chancellors. This mirrors the arguments emerging from the UK Jarratt report in 1985 where Vice Chancellors were told they should become Chief Executives of the corporate enterprise that is the university, embracing strategic planning and setting up systems for managing the education business. ${ }^{51}$ Similarly, Marginson and Considine $^{52}$ demonstrate that the new organisations to be put in place by these managers include 'system level change [that] created a more competitive

\footnotetext{
${ }^{48} \mathrm{~L}$ Hammersley-Fletcher and A Qualter, 'Chasing improved pupil performance: the impact of policy change on school educators' perceptions of their professional identity, the case of further change in English schools' (Paper presented at the Canadian Association for the Study of Educational Administration, University of British Columbia, Vancouver, May $30^{\text {th }}-$ June $4^{\text {th }} 2008$ )

49 L Hammersley-Fletcher and A Qualter 'Chasing improved pupil performance: the impact of policy change on school educators' perceptions of their professional identity, the case of further change in English schools' under review with a journal

${ }^{50}$ B Davies, M Gottsche, and P Bansel, 'The Rise and Fall of the Neo-liberal University' European Journal of Education , 41, (2), (2006): 305-319

${ }^{51} \mathrm{M}$ Henkel, 'The demise if the dominant culture: Higher Education instituitions in transition' Learning and Teaching in the Social Sciences 1 (1) (2004): 21-32

${ }^{52} \mathrm{~S}$ Marginson and M Considine, The enterprise university: power, governance and reinvention in Australia (Cambridge: Cambridge University Press, 2000): 28
} 
relationship between individual institutions, installed efficiency imperatives in day to day conduct, and encouraged the emergence of entrepreneurial management focused on the bottom line'. Davies et al argue that this streamlining is not simply done to reduce costs, indeed the proliferation of accountability systems are extremely costly, but to make universities more governable and more acquiescent to notions of working with big business.

In the current climate the purpose of universities from a policy maker's point of view, is to serve the economic interests of society.

In a fast-changing and increasingly competitive world, the role of higher education in equipping the labour force with appropriate and relevant skills, in stimulating innovation and supporting productivity and in enriching the quality of life is central. ${ }^{53}$

At the same time there are strong arguments that Universities should embody higher ideals relating to the enrichment and in the case of Liverpool University, "The pursuit of knowledge and the ennoblement of life". Universities, including the Vice Chancellors charged with managing them, struggle with achieving a balance between the pursuit of knowledge for its own sake and service to society.

Universities should do teaching and research because the pursuit of knowledge is both an end in itself and a means to an end. As an end in itself, the individual wants to pursue it. As a means to an end, society needs to have it pursued. The task of universities is to bring the end and the means together. They should do research and teaching in such a manner that their supply of knowledge connects in a mutually beneficial relationship with the needs emanating from society. In that way, the pursuit of knowledge becomes both a private benefit and a public good. ${ }^{54}$

Following an argument put by Kerr and since developed by a number of others, Gumport $^{55}$ suggests that this point in time is a defining moment in the history of Higher Education. Drawing on an extensive set of case studies in US public universities and colleges, Gumport argues that reorganisation of universities, in the spirit of greater efficiency, accountability, and fitness for modern needs is also a repurposing of the university. Meeting the demands of industry and the economy may be served by tighter management and more streamlined structures. It may be better served by more careful development of courses of study to meet the needs of

\footnotetext{
${ }^{53}$ DIUS 'The Future of Higher Education - White paper' DCSF http://www.dcsf.gov.uk/hegateway/strategy/hestrategv/ (accessed January 2009)

${ }^{54} \mathrm{C}$ Brink 'What are Universities for?' (Lecture by Professor Chris Bink, Vice Chancellor Newcastle University, 27 November 2007) Newcastel University http://www.ncl.ac.uk/documents/whatareuniversitiesfor.pdf. (accessed January 2009)

55 P Gumport, 'Academic restructuring: Organizational change and institutional imperatives' Higher Education, 39 (2000): 67-91
} 
customers. In reorganising to meet these needs however, the purposes of the university may de facto be changed.$^{56}$ Meeting the core educational and socialisation functions could, without careful consideration become peripheral to the new university purpose and so need to be distributed to other institutions, thus tipping the balance towards the needs of the customer.

How university academics see their role and in turn how their identity as academics develops reflects the current balancing act. Identity formation is an ongoing process of reflection and negotiation within a particular group or culture, thus a certain degree of stability and continuity is required for professional academic identities to form. Such identities are developed through the engagement of individuals within a wider group of academics through mutual recognition for the status of members of the discipline and the subsequent sharing of myths and language of the group. ${ }^{57}$ To enter Higher Education is to engage in an immensely complex arena with significant variation between and within institutions and ever increasing demands on those institutions to deliver across a number of externally and internally driven agendas. Further Silver, ${ }^{58}$ who explored the idea of a university culture, concluded that they do not have a single culture, but that they are collections of subunits each with their own culture. Williams ${ }^{59}$ citing Piper argues that academe is a specialised occupation based on expert (discipline related) knowledge. Consequently he suggests that there is not one academic profession, but a number of professions each tied to the discipline rather than the institution. Academic disciplines cut across universities providing a platform within which academic identities can be formed. These disciplines, often gathered in whole departments or subdivisions of departments, also need to operate within the wider institution. Thus, in Knight and Trowler's ${ }^{60}$ terms there are numerous 'activity systems' or structures within which individual professionals must operate.

Stronach and colleagues ${ }^{61}$ argue that professions develop in two ways. First, from the inside out, that is, through the sharing of the mores, practices, tacit understandings and experiences of the professional group mediated and shaped by the hierarchies within. Here the group defines itself to the outside world. Second, academic groups must interact with the increasingly managerial and performative systems that prevail in universities and so the outside-in serves to provide an

\footnotetext{
${ }^{56}$ R Barnett, (2004) 'The Purposes of Higher Education and the Changing Face of Academia' London Review of Education,2 (1), (2004): 61-73

${ }^{57}$ R Jenkins, Social Identity (London: Routledge, 1996)

${ }^{58} \mathrm{H}$ Silver, 'Does a University Have a Culture?', Studies in Higher Education, 28 (2), (2003): 157- 169

${ }^{59} \mathrm{~K}$ Williams, 'Troubling the concept of the "academic profession" in 21st Century higher education' Higher Education, 56, (2008): 533-544

${ }^{60}$ P Knight, and P R Trowler, 'Department-level Cultures and the Improvement of Learning and Teaching' Studies in Higher Education 25, (1),(2000): 69-83

${ }_{61}$ I Stronach, B Corbin, O McNamara, S Stark and T Warne, 'Towards an uncertain politics of professionalism: Teacher and nurse identities in flux' Journal of Education Policy, 17(1), (2002): 109-138.
} 
external definition of the professional group, and indeed the external measures of quality and success in meeting the demands of the institution. This in turn supports national and international policy on the purpose of universities. Academics within universities inevitably find themselves steering a tricky path as they develop their careers alongside their identities as academics.

What is very clear is that academics view themselves as members of a collegial group albeit a group that operates across two planes, the disciplinary and the departmental. In Universities however, Henkel ${ }^{62}$ found, in an interview study, that the most dominant theme was that of academic freedom. This encompassed the freedom to choose one's own direction for research and having confidence in being trusted to manage one's own working life. ${ }^{63}$ Thus disciplinary knowledge, autonomy in choosing ones own direction and having responsibility conferred by the trust they expect from their institution was of prime importance. This is described in the breech by a mid career physicist from a pre 1922 university in Henkel's study.

It is not simply a matter of time. It is a matter of attitude and atmosphere that is de-motivating. There is a feeling that one is being manipulated by $\ldots$ administrators, required to provide statistics, to make cases for all sorts of things that you should not be asked to do ... [There is] an implication that you are wasting tax payers' money; that you are not an independent professional who can exercise judgement about these things without having to justify them to an administrator. ${ }^{64}$

This statement includes within it reference to the increased influence of the external university systems designed to measure performance and in turn increase efficiency. The role of the academic is coming under increasing scrutiny as the audit culture reaches saturation point with the introduction in recent years of systems for measuring research output. Two examples are The 'Research Assessment Exercise' in the UK, and the most recent, 2008 iteration for Australia, Excellence in Research for Australia. Other audits, such as the Quality Assurance Agency (QAA) in England, look closely at the systems for managing learning and teaching. The emphasis of QAA is on the appropriateness of institutional systems and processes in managing and enhancing quality and standards. Discussion in England as part of a review of Higher Education have recently suggested that greater strictures might need to be placed on Higher Education in order to ensure delivery of consistently high standards. This has led Vice Chancellors to fear the imposition of greater regulation..$^{65}$ Other challenges have emerged in the recent debate in the Time Higher

\footnotetext{
${ }^{62} \mathrm{M}$ Henkel, 'The demise if the dominant culture: Higher Education instituitions in transition' Learning and Teaching in the Social Sciences 1 (1) (2004): 21-32

${ }^{63} \mathrm{G}$ Neave, 'On the Cultivation of Quality, Efficiency and Enterprise: An Overview of Recent Trends in Higher Education in Western Europe, 1986-1988' European Journal of Education, 23 (1-2) (1988): 7-23

${ }^{64}$ M Henkel: 26

65 'VCs Accuse Select Committee of 'Obsession' Times Higher Education 7 April 2007
} 
Education by Atwood who described the external examiner system as "a sham", a system that is "too often abused"; it is "obsolete" and serves only as "a fig leaf". 66 Such criticism serves to further undermine the capacity of academics to set quality standards and make judgements about each others practices and has provoked fierce debate.

Thus, universities are expected to self-assess, but, they are not free to determine what they value, nor what should be measured. These systems are designed to encourage choice by students, research funding bodies and businesses in the belief that this will drive up standards, improve the 'fit' between industry needs and university product and enhance international competitiveness. Yet, at the same time, in defining the standards to be achieved universities and the academics within them have reduced room to manoeuvre. Henkel ${ }^{67}$ argues that from the late 1970's research councils had to adopt more rationalist managerial structures in making awards. Moreover, industrialists have increasing influence on research councils and other funding bodies emphasizing 'useful' research. Thus funding for research where no immediate application can be envisaged is less likely to succeed. Reflecting this shift in the planned research exercise for 2014, one suggested indicator of quality will be that of 'impact'. Alongside this, government funding for universities has been shrinking giving the quest for research income a higher imperative.

Some indicators of the effects such changes have had on academic freedoms is reported by $\operatorname{Archer}^{68}$ from a small scale interview study of eight academics under the age of thirty five. All interviewees held similar values, of criticality, autonomy and professionalism, to those reported from studies of older respondents. They also saw collegiality and collaboration alongside the importance of the development of their own identity as 'personal principled projects'. ${ }^{69}$ They rejected the notion that there was a golden age of freedom in the past, but recognised changes in the pressures upon them to produce research papers, grants or to teach more modules, and to deliver in ever tighter timescales. Some felt a sense of loss or disillusionment at not having time to think, to exercise their criticality and autonomy. This group of staff were 'Thatchers children' in that they saw little alternative to the systems as they are, but felt that they just needed to ease off the pressure a little. In this way, as Archer suggests, the study concurs with Davies and Petersen's pessimistic conclusion that it is not possible to resist the neoliberal agenda, as 'governance is enacted via hearts and minds' ${ }^{70}$ Archer however, does identify ways in which these early career academics were finding 'spaces' in which to develop their own 'project', to think critically, and to challenge accepted norms. These 'spaces' are of crucial importance to the future of academia, as surely it is here that the pursuit of

\footnotetext{
${ }^{66} \mathrm{R}$ Attwood 'Outside looking in' Times Higher Education $25^{\text {th }}$ June 2009

${ }^{67} \mathrm{M}$ Henkel

${ }^{68} \mathrm{~L}$ Archer, "'The new neoliberal subjects? Younger academics" constructions of professional identity' Journal of Education Policy, 23 (3), (2008): 265-285

${ }^{69}$ L Archer: 207

${ }^{70}$ L Archer
} 
knowledge through teaching and research as an end in itself and not only as a means to an end, is achieved.

\section{Conclusion}

Hoyle ${ }^{71}$ claimed that professional occupations have previously had the freedom and responsibility go from conception to delivery of a problem within their field of expertise or licence. Thus teachers in England were able to determine the curriculum (what to teach), and to decide how to teach it. For academics the issue is couched in terms of academic freedom where the operation of subject focussed networks have played a significant role in influencing the thinking and agendas of subject development. Neoliberal agendas have, we argue, significantly re-shaped the arena within which educational institutions operate. Through the exemplars of primary schools and Universities we have shown how roles or the nature of the work has been subdivided and bound. Regulatory agendas ostensibly designed to protect the rights and freedoms of the individual have served to regulate the work of educators and to restrict what they do. That is the identification of a problem, conception of a solution and implementation of that solution has been taken out of the hands of the individual and passed to external systems of accountability, nationally devised curricula or even detailed benchmark statements and league tables of performance against criteria or student opinion. All of these act to reduce the freedom of the professional to choose what and how to teach or where to focus their energies in research.

Through the critical examination of the neoliberal and managerialist pressures on two sites of educational practice we can argue that in primary schools teachers freedoms have in most cases been successfully eroded with teachers operating within an increasingly narrow set of alternatives. There is nevertheless some potential for re-capturing some autonomy and creativity through new collaborations and partnerships developing around agendas such as that of Extended Schools. As primary schools work to understand and collaborate with a wider range of agencies, then the potential for them to re-evaluate their own practices and understandings of education increases. Such outcomes are however only possible if head teachers facilitate and enable such development and are prepared to support outcomes which may not always match external agendas for change. Academia faces similar sets of restrictions to schools in terms of accountability agendas and carefully targeted research funding. The greater complexity of the organisation however presents a very particular challenge, and whilst this may afford sufficient complexity to stave off the damaging effects of excess of managerialism, it is important that academics

\footnotetext{
71 E Hoyle, 'Changing conceptions of a profession' in $\mathrm{H}$ Busher and $\mathrm{R}$ Saran, Managing Teachers as professionals in Schools (London: Routledge, 1995)
} 
remain alert to the threats posed. Whilst individual staff loyalties tend to be focussed within subject networks and areas of expertise and where staff continue to find the 'spaces in between' indentified by Archer ${ }^{72}$ then it is more difficult to convince them of the need to follow prescribed courses of action to the exclusion of the pursuit of their own 'projects'. In both cases illustrated above we have argued that creative managers and leaders can provide teaching and academic staff with the spaces necessary to develop and instigate creative practice. These spaces however, are under increasing threat. Thus pressures which act to sub-divide each site of educational delivery should be viewed as a threat to autonomy. Developing a balance between the institutional aims and strategies and maintaining the individual or groups independence, presents a significant challenge.

We have argued above that boundaries play a significant role in restricting the work of educators and that these boundaries are more difficult to maintain where networks of practitioners operate. Collaborative initiatives tend to lead those within them to consider a variety of solutions to a problem. In addition to this we have glimpsed the effect that a Head Teacher in a primary school can, by thoughtful management of people, careful staff development and retaining concern for learning, ward off the excesses of the external agenda. Equally in Universities heads of department need to protect their staff from activities which encroach on the 'spaces' necessary to allow for creative development that may be unplanned and that is certainly lopsided. Thus we argue that in order to tackle such a challenge, the roles of leaders and managers in education are of key importance. Through protecting spaces and encouraging educational practitioners to collaborate and discuss their purposes education can continue to enrich and enhance the quality of life.

\footnotetext{
${ }^{72}$ L Archer
} 